\section{D) Check for updates}

Cite this: Mater. Adv., 2020 1, 1307

Received 5th May 2020,

Accepted 30th June 2020

DOI: $10.1039 / \mathrm{d} 0 \mathrm{ma00277a}$

rsc.li/materials-advances

\title{
The interfacial degradation mechanism of polymer:fullerene bis-adduct solar cells and their stability improvement $\dagger$
}

\author{
Lingpeng Yan, ${ }^{\text {ab }}$ Huimin Gu, ${ }^{\text {ac }}$ Zerui Li, ${ }^{a}$ Jianqi Zhang, (D) ${ }^{d}$ Yongzhen Yang, (D) *c \\ Hua Wang, (D) Xuguang Liu, (D) ${ }^{\mathrm{b}}$ Zhixiang Wei, (iD) d Qun Luo iD a and \\ Chang-Qi $\mathrm{Ma}$ (D)*a
}

\begin{abstract}
Although fullerene bis-adducts have been widely used in polymer solar cells for their high LUMO energy level and good performance, the degradation behavior of this class of solar cells has not been well understood. In this paper, the performance and stability of the solar cells based on P3HT:fullerene bisadducts, including bis- $\mathrm{PC}_{61} \mathrm{BM}$ and $\mathrm{ICBA}$, were systematically investigated. Different from the P3HT:PC ${ }_{61} B M$ cell, these bis-adduct based cells showed fast open circuit $\left(V_{O C}\right)$ and fill factor (FF) decays. The partial recovery of $V_{\mathrm{OC}}$ and FF of the aged cells by renewing the $\mathrm{MoO}_{3} / \mathrm{Al}$ electrode indicated that degradation at the photoactive layer and $\mathrm{MoO}_{3}$ interface is the main reason for $V_{\mathrm{OC}}$ and FF decays. The X-ray photoelectronic spectroscopy analysis confirmed that under light illumination, $\mathrm{Mo}^{6+}$ of $\mathrm{MoO}_{3}$ is partially reduced to $\mathrm{Mo}^{5+}$. By inserting a thin layer of $\mathrm{C}_{60}$, both $\mathrm{MoO}_{3}$ reduction and performance decays are slowed down, confirming that photoreduction of $\mathrm{MoO}_{3}$ by P3HT is the degradation mechanism for $\mathrm{P} 3 \mathrm{HT}$ :bis- $\mathrm{PC}_{61} \mathrm{BM}$ cells. Finally, we found that doping a polymer:fullerene bisadduct layer with piperazine increases the fullerene content on the surface of the photoactive layer, which consequently lowers the reduction of $\mathrm{Mo}^{6+}$ and improves the stability of the solar cells. This work gives a detailed understanding of the interfacial degradation of PSCs and provides effective solutions, which has important guiding significance for improving the stability of different types of polymer solar cells.
\end{abstract}

\section{Introduction}

Polymer solar cells (PSCs) have seen rapid development in recent years with the power conversion efficiency (PCE) boosted to over $17 \%^{1,2}$ for single junction solar cells and $11.7 \%^{3}$ for large-area modules. Owing to their high electron affinity and mobility, fullerene and its derivatives have been universal acceptor materials for PSCs for the past two decades. ${ }^{4-6}$ Although nonfullerene acceptors are currently dominating the research and development of PSCs, fullerene derivatives still play a pivotal role

\footnotetext{
${ }^{a}$ Printed Electronics Research Center, Suzhou Institute of Nano-Tech and Nano-Bionics, Chinese Academy of Sciences (CAS), Suzhou 215123, P. R. China. E-mail: cqma2011@sinano.ac.cn

${ }^{b}$ Institute of New Carbon Materials, Taiyuan University of Technology, 79 Yingze Street, Taiyuan 030024, P. R. China

${ }^{c}$ Key Laboratory of Interface Science and Engineering in Advanced Materials, Ministry of Education, Taiyuan University of Technology, Taiyuan 030024, P. R. China. E-mail: yyztyut@126.com

${ }^{d}$ CAS Key Laboratory of Nanosystem and Hierarchical Fabrication, CAS Center for Excellence in Nanoscience, National Center for Nanoscience and Technology, Beijing 100190, P. R. China

$\dagger$ Electronic supplementary information (ESI) available. See DOI: 10.1039/d0ma00277a
}

in high performance ternary ${ }^{7-9}$ or tandem cells. ${ }^{2}$ In the fullerene acceptor family, $[6,6]$-phenyl- $\mathrm{C}_{61}$-butyric acid methyl ester $\left(\mathrm{PC}_{61} \mathrm{BM}\right)$ and $[6,6]$-phenyl- $\mathrm{C}_{71}$-butyric acid methyl ester $\left(\mathrm{PC}_{71} \mathrm{BM}\right)$ are the two most used acceptors in PSCs for their good solubility, high electron mobility, and matched energy levels with a wide range of polymer donors. ${ }^{10-12}$ Beyond them, the fullerene bis-adducts like the bisadduct of phenyl- $\mathrm{C}_{61}$-butyric acid methyl ester (bis- $\mathrm{PC}_{61} \mathrm{BM}$ ) and the indene- $\mathrm{C}_{60}$ bis-adduct (ICBA, see Fig. 1 for the chemical structure) also attract much attention for their high-lying lowest unoccupied molecular orbital (LUMO) levels, which is good for achieving high open circuit voltage $\left(V_{\mathrm{OC}}\right)$ of the cells, ${ }^{9,13-15}$ since the $V_{\mathrm{OC}}$ of PSCs is almost directly proportional to the gap between the highest occupied molecular orbital (HOMO) level of the donor and the LUMO level of the acceptor. ${ }^{16,17}$ The high $V_{\mathrm{OC}}$ is especially important in tandem solar cells. For example, You et al. reported tandem PSCs using P3HT:ICBA as the front cell, in which a high $V_{\mathrm{OC}}$ of $1.53 \mathrm{~V}$ was achieved. ${ }^{6}$

With the increase of power conversion efficiency, the stability of PSCs has been recognized as the next most important issue to be solved before the commercialization of PSCs. Numerous studies have shown that most PSCs exhibit a fast exponential "burn-in" degradation, which dominates the overall performance 
(a)

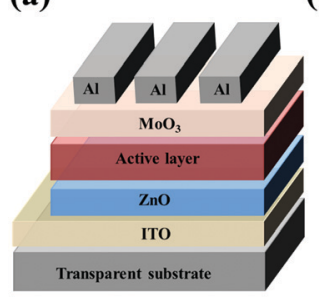

(b)

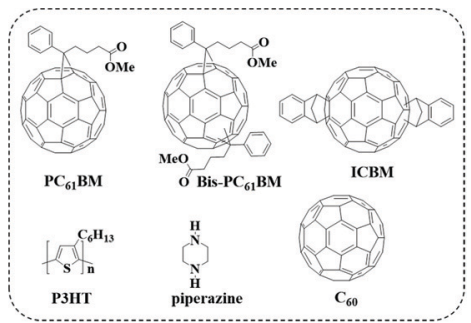

Fig. 1 Device structure (a) of PSCs, and molecular structures (b) of $\mathrm{PC}_{61} \mathrm{BM}$, bis- $\mathrm{PC}_{61} \mathrm{BM}, \mathrm{ICBA}, \mathrm{C}_{60}, \mathrm{P} 3 \mathrm{HT}$, and piperazine

decay of PSCs. ${ }^{18,19}$ For PC $_{61}$ BM based solar cells, it was reported that photon-induced dimerization is the main reason for the "burn-in" decay of PSCs, where short circuit current $\left(J_{\mathrm{SC}}\right)$ decay dominates the decay process. ${ }^{20-22}$ Our recent work further proved that such a "burn-in" degradation is dependent on the external load. Therefore, we ascribed the formation of $\mathrm{PC}_{61} \mathrm{BM}$ dimers to the triplet state related photo dimerization. ${ }^{22}$ On the basis of this finding, doping the polymer:fullerene film with a triplet quencher for fullerene molecules - organic amines, such as piperazine - is able to suppress the "burn-in" process, and less than $10 \%$ performance decay after light illumination over $1000 \mathrm{~h}$ was achieved. ${ }^{23}$ The bis-substituted $\mathrm{C}_{60}$ derivatives are not prone to dimerization due to steric hindrance, ${ }^{24}$ however, as will be shown later in this paper, that the fast degradation of fullerene bis-adduct based PSCs occurs as well, which suggests a different degradation mechanism for the polymer:fullerene bis-adduct solar cells. To date, no research work was reported on the degradation mechanism of fullerene bis-adduct based PSCs.

Since fullerene bis-adducts have shown potential application in high performance tandem or ternary solar cells for their high lying LUMO energy level, it is still of high interest to investigate the degradation behavior of this class of cells. In this paper, for the first time, we systematically investigate the degradation behaviors of P3HT:fullerene bis-adduct (both bis- $\mathrm{PC}_{61} \mathrm{BM}$ and ICBA) cells. Unlike $\mathrm{PC}_{61} \mathrm{BM}$ cells, where $J_{\mathrm{SC}}$ decays dominate the overall performance degradation, these fullerene bis-adduct based solar cells also showed fast open circuit $\left(V_{\mathrm{OC}}\right)$ and fill factor $(\mathrm{FF})$ decays. By analyzing the interfacial properties of the solar cells during degradation, it can be clearly proved that the interfacial photoreduction of the $\mathrm{MoO}_{3}$ layer by a conjugated polymer is the main reason leading to the fast $V_{\mathrm{OC}}$ and $\mathrm{FF}$ decays. Based on this finding, the methods to improve the stability of the cells are established, including doping the photoactive layer with piperazine and depositing a thin layer of $\mathrm{C}_{60}$ on the surface of the active layer. The current work gives a detailed understanding of the interfacial degradation of polymer:fullerene cells, which will guide in improving the stability of different types of polymer solar cells.

\section{Experimental}

\subsection{Materials}

Regioregular poly(3-hexylthiophene) (SMI-P3HT, $M_{\mathrm{n}}=5.0 \times$ $10^{4} \mathrm{~g} \mathrm{~mol}^{-1}$ ), $\mathrm{PC}_{61} \mathrm{BM}$, bis-PC ${ }_{61} \mathrm{BM}$, and ICBA were purchased from Solarmer Materials Inc. (Beijing). $\mathrm{C}_{60}$ was provided by Suzhou Dade Carbon Nanotechnology Co. Ltd. Piperazine was obtained from J\&K China Chemical Co. Ltd. ZnO nanoparticles were synthesized by the reaction of $\mathrm{KOH}$ and $\mathrm{Zn}(\mathrm{OAc})_{2}$ in methanol solvent as reported by Beek et al. ${ }^{25,26}$

\subsection{Fabrication of inverted solar cells}

Inverted PSCs with an architecture of ITO/ZnO/active layer/ $\mathrm{MoO}_{3} / \mathrm{Al}$ were fabricated. The patterned ITO glass substrates were cleaned using a detergent, deionized water, acetone and isopropanol, then the precleaned ITO glass substrates were blown using a nitrogen gun and subsequently treated with UV-ozone for $30 \mathrm{~min}$. Filtered $\mathrm{ZnO}\left(10 \mathrm{mg} \mathrm{mL}^{-1}\right.$ in methanol) was spin-coated onto the ITO glass substrates at $2500 \mathrm{rpm}$ for $60 \mathrm{~s}$ and baked at $120{ }^{\circ} \mathrm{C}$ for $10 \mathrm{~min}$ in a $\mathrm{N}_{2}$-filled glovebox. Then, the active layers (P3HT: $\mathrm{PC}_{61} \mathrm{BM}, \mathrm{P} 3 \mathrm{HT}$ :bis- $\mathrm{PC}_{61} \mathrm{BM}$, and P3HT:ICBA) were spin coated on the $\mathrm{ZnO}$ layers. The blend solutions of P3HT:PC ${ }_{61} \mathrm{BM}$ ( $40 \mathrm{mg} \mathrm{mL}^{-1}$ in 1,2-dichlorobenzene (o-DCB) and a donor : acceptor ratio of $1: 1)$, P3HT:bis- $\mathrm{PC}_{61} \mathrm{BM}$ ( $44 \mathrm{mg} \mathrm{mL}^{-1}$ in $o$-DCB and donor : acceptor ratio of $1: 1.2$ ) and P3HT : ICBA ( $40 \mathrm{mg} \mathrm{mL}^{-1}$ in $o$-DCB and donor : acceptor ratio of $1: 1)$ were mixed with varying amounts of piperazine additives $(0,0.5,1,5$ and $10 \mathrm{wt} \%$ based on the total weight of the active layer materials) and stirred at $50{ }^{\circ} \mathrm{C}$ overnight. The mixture solutions were spin-coated at $600 \mathrm{rpm}$ for $60 \mathrm{~s}$ onto $\mathrm{ZnO}$ layers. Then, the wet blend films were put into covered Petri dishes for $2 \mathrm{~h}$. Subsequently, the active layers were annealed at $120{ }^{\circ} \mathrm{C}$ for $10 \mathrm{~min}$ in a $\mathrm{N}_{2}$-filled glove box. Finally, $\mathrm{MoO}_{3}(10 \mathrm{~nm})$ and $\mathrm{Al}$ $(100 \mathrm{~nm})$ were sequentially vacuum deposited on top of the active layer at pressure $<5 \times 10^{-4} \mathrm{~Pa}$. For devices with C60 insertion, before the deposition of $\mathrm{MoO}_{3} / \mathrm{Al}$, C60 films of different thicknesses $(0-6 \mathrm{~nm})$ were vacuum evaporated onto the active layer at pressure $<5 \times 10^{-4} \mathrm{~Pa}$. The effective photovoltaic area, defined by the geometrical overlap between the bottom cathode electrode and the top anode, was $0.09 \mathrm{~cm}^{2}$. The molecular structures of $\mathrm{P} 3 \mathrm{HT}, \mathrm{PC}_{61} \mathrm{BM}$, bis- $\mathrm{PC}_{61} \mathrm{BM}$, ICBA, $\mathrm{C}_{60}$ and piperazine as well as the device structure are shown in Fig. 1.

\subsection{Sample preparation for XPS and UPS characterization}

The samples for X-ray photoelectron spectroscopy (XPS) and Ultraviolet Photoelectron Spectroscopy (UPS) characterization were prepared and tested in an inert atmosphere or under vacuum to eliminate the influence of air. Clean ITO glass substrates were treated with UV-ozone for $10 \mathrm{~min}$. Then, P3HT:bis-PC ${ }_{61} \mathrm{BM}(150 \mathrm{~nm})$ films were spin coated on the ITO glass. The wet blend films were then put into covered Petri dishes for $2 \mathrm{~h}$. Subsequently, the active layers were annealed at $120{ }^{\circ} \mathrm{C}$ for $10 \mathrm{~min}$. Finally, $\mathrm{MoO}_{3}(5 \mathrm{~nm})$ was vacuum deposited on top of the active layer at pressure $<5 \times 10^{-4} \mathrm{~Pa}$. After that, the samples were illuminated with a white LED for 0 or $5 \mathrm{~h}$, and the illumination is performed from the $\mathrm{MoO}_{3}$ side. All the above experimental processes were carried out in a $\mathrm{N}_{2}$-filled glove box. At last, the samples were put into a $\mathrm{N}_{2}$-filled transition chamber and taken to the test center, where the samples were directly vacuumed and tested. 


\subsection{Characterization}

Characterization of active layers. Atomic force microscopy (AFM) images of the films were recorded using a Dimension 3100 atomic force microscope. The Grazing-incidence wideangle X-ray scattering (GIWAXS) was tested using a XEUSS saxs/waxs system, Xenocs (France). XPS, ARXPS (angle resolved XPS) and UPS characterization was performed on a PHI 5000 Versa Probe III X-ray photoelectron spectroscope. The $\mathrm{C} / \mathrm{S}$ and $\mathrm{C}-\mathrm{O} / \mathrm{C}-\mathrm{C}$ ratios are the average values of the three sets of test data. The absorption spectra of films were measured using a Lambda 750 UV/vis/NIR spectrophotometer (PerkinElmer).

PSC performance characterization. The $J-V$ curves of PSCs were recorded in a glove box using a Keithley 2400 source meter under illumination with simulated AM 1.5G sunlight (ss150 solar simulator, Zolix). The external quantum efficiency (EQE) spectra were recorded under illumination by a simulated one sun operation condition using bias light from a $532 \mathrm{~nm}$ solid state laser. Light from a $150 \mathrm{~W}$ tungsten halogen lamp (Osram 64610) was used as a probe light and was modulated with a mechanical chopper before passing through the monochromator (Zolix, Omni-k300) to select the wavelength. The response was recorded as the voltage using an $I-V$ converter (DNR-IV Convertor, Suzhou D\&R Instruments), using a lock-in amplifier (Stanford Research Systems SR 830). A calibrated Si cell was used as a reference. The device for EQE measurement was kept behind a quartz window in a nitrogen-filled container.

PSC long-term stability testing. The long-term stabilities of unencapsulated devices were tested using a multi-channel solar cell performance decay test system (PVLT-G8001 M, Suzhou D\&R Instruments) under testing conditions in accordance with ISOS-L-1. The unencapsulated devices were put inside a glove box $\left(\mathrm{H}_{2} \mathrm{O}<10 \mathrm{ppm}, \mathrm{O}_{2}<10 \mathrm{ppm}\right)$ and continuously illuminated with a LED light (LED array white light, with a color temperature of 5300 K, D\&R Light, L-W5300KA-150, Suzhou D\&R Instruments). The LED light has a spectral range of $400-870 \mathrm{~nm}$. The illumination light intensity was initially set so the output $J_{\mathrm{SC}}$ of devices equaled the $J_{\mathrm{SC}}$ measured under standard conditions. The illumination light intensity was monitored by a photodiode (Hamamatsu S1336-8BQ). The $J-V$ curves were periodically swept every half an hour, and the $V_{\mathrm{OC}}, J_{\mathrm{SC}}, \mathrm{FF}$, and power conversion efficiency (PCE) were recorded. During testing, the device was attached to an external load to match the maximum power output point (mpp), where the load value $\left(R_{100}\right)$ was then calculated according to the equation $R_{100}=V_{\max } / I_{\max }$, where $V_{\max }$ and $I_{\max }$ represent the voltage and current at the mpp point.

\section{Results and discussion}

\subsection{Degradation of P3HT:fullerene solar cells}

In this work, P3HT was chosen as the donor, because it is the most well investigated polymer and the degradation behaviors of P3HT:PC 61 BM solar cells have been well studied. ${ }^{22,27,28} \mathrm{We}$ fabricated the P3HT PSCs based on different fullerenes $\left(\mathrm{PC}_{61} \mathrm{BM}\right.$, bis- $\mathrm{PC}_{61} \mathrm{BM}$ and ICBA $)$ and tested the device performance under standard conditions. Fig. 2 shows the $J-V$ curves and EQE spectra of the cells, and Table 1 lists the device characteristics. The P3HT:PC ${ }_{61} \mathrm{BM}$ solar cells show the best PCE of $3.56 \%$, with $V_{\mathrm{OC}}$ of $0.60 \mathrm{~V}, J_{\mathrm{SC}}$ of $10.07 \mathrm{~mA} \mathrm{~cm} \mathrm{~cm}^{-2}$ and $\mathrm{FF}$ of 0.59 , similar to our previous works. ${ }^{23}$ For the fullerene bis-adduct solar cells, the devices show higher PCE (4.09\% for P3HT:bis-PC ${ }_{61} \mathrm{BM}$ cells and $4.53 \%$ for P3HT:ICBA cells), which is mainly due to their higher $V_{\mathrm{OC}}$ (0.73 V for P3HT:bis- PC $_{61} \mathrm{BM}$ cells and $0.85 \mathrm{~V}$ for P3HT:ICBA cells), originating from their higher LUMO levels. ${ }^{14,29}$ All these cells show comparable device performance to those reported in the literature, ${ }^{14,29}$ and the PCE distribution is rather narrow, making them suitable for device degradation behavior study.

Fig. 3 depicts the evolution of the $V_{\mathrm{OC}}, J_{\mathrm{SC}}$, FF and PCE of solar cells aged at mpp with continuous light illumination. As can be seen here, P3HT:PC ${ }_{61} \mathrm{BM}$ solar cells undergo a strong "burn-in" loss under operation conditions. After being aged for 200 h, P3HT:PC ${ }_{61}$ BM cells display an overall 48\% PCE degradation, where $J_{\mathrm{SC}}$ decay $(41 \%)$ dominates the overall performance loss. Both P3HT:bis-PC ${ }_{61}$ BM and P3HT:ICBA solar cells show also fast

Table 1 Photovoltaic parameters of P3HT:acceptor solar cells ${ }^{a}$

\begin{tabular}{lllll}
\hline Acceptor & $J_{\mathrm{SC}}\left(\mathrm{mA} \mathrm{cm}^{2}\right)$ & $V_{\mathrm{OC}}(\mathrm{V})$ & $\mathrm{FF}$ & $\mathrm{PCE}^{b}(\%)$ \\
\hline $\mathrm{PC}_{61} \mathrm{BM}$ & 10.07 & 0.60 & 0.59 & 3.56 \\
& $(9.98 \pm 0.15)$ & $(0.60 \pm 0.001)$ & $(0.59 \pm 0.012)$ & $(3.50 \pm 0.15)$ \\
bis-PC $_{61} \mathrm{BM}$ & 9.18 & 0.73 & 0.62 & 4.15 \\
& $(9.14 \pm 0.11)$ & $(0.73 \pm 0.007)$ & $(0.61 \pm 0.016)$ & $(4.07 \pm 0.17)$ \\
ICBA & 9.69 & 0.85 & 0.55 & 4.53 \\
& $(9.61 \pm 0.15)$ & $(0.84 \pm 0.003)$ & $(0.55 \pm 0.003)$ & $(4.44 \pm 0.09)$
\end{tabular}

${ }^{a}$ The best cell. ${ }^{b}$ The number in brackets is the averaged PCE over 8 individual devices.
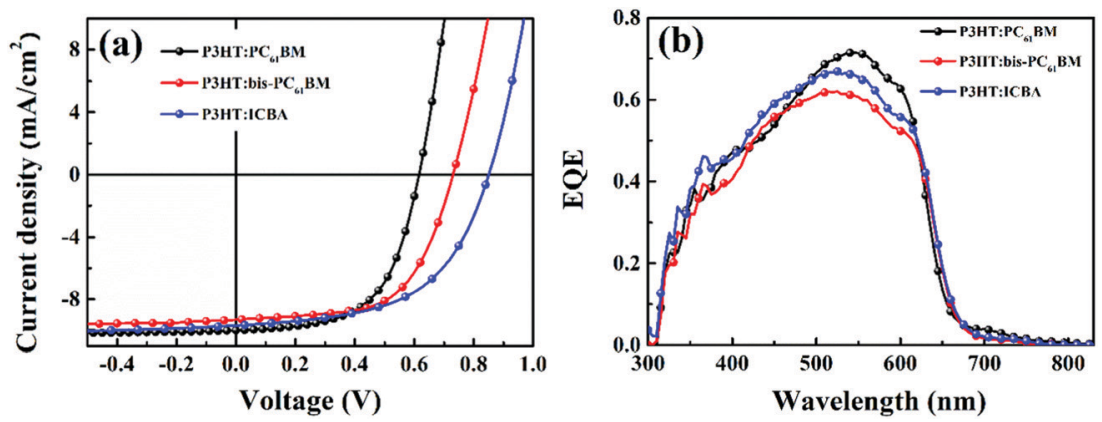

Fig. $2 \mathrm{~J}-V$ curves (a) and EQE spectra (b) of P3HT:PC ${ }_{61} B M, P 3 H T$ :bis- $P_{61} B M$ and P3HT:ICBA solar cells. 

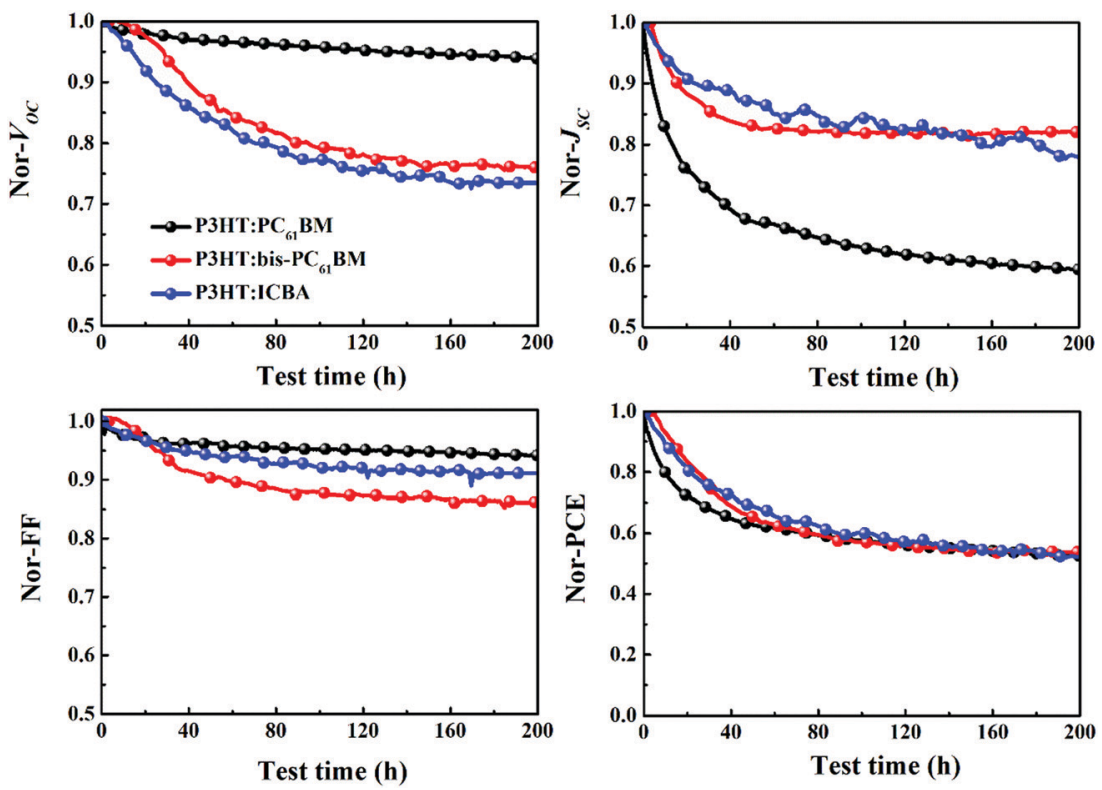

Fig. 3 Evolution of the $V_{\mathrm{OC}}, J_{\mathrm{SC}}, \mathrm{FF}$ and $\mathrm{PCE}$ of P3HT:PC ${ }_{61} \mathrm{BM}, \mathrm{P} 3 \mathrm{HT}$ :bis-PC ${ }_{61} \mathrm{BM}$ and $\mathrm{P} 3 \mathrm{HT}$ :ICBA solar cells aged at mpp with continuous light illumination.

"burn-in" degradation, however, $V_{\mathrm{OC}}$ decay is more prominent than $J_{\mathrm{SC}}$ decay. After being aged for $200 \mathrm{~h}, \mathrm{P} 3 \mathrm{HT}$ :bis-PC ${ }_{61} \mathrm{BM}$ solar cells show $47 \%$ PCE degradation, with $24 \% V_{\text {OC }}$ decay, $19 \% J_{\text {SC }}$ decay and 14\% FF decay, while P3HT:ICBA solar cells show 48\% PCE degradation, with $27 \% V_{\mathrm{OC}}$ decay, $23 \% J_{\mathrm{SC}}$ decay and $9 \% \mathrm{FF}$ decay. The faster decay of $V_{\mathrm{OC}}$ and FF for fullerene bis-adduct based solar cells suggests that their degradation mechanism is different from that of $\mathrm{PC}_{61} \mathrm{BM}$ based solar cells. In the following section, we will focus the exploration on the degradation mechanism of the P3HT:bis-PC ${ }_{61} \mathrm{BM}$ solar cells.

\subsection{Understanding of the degradation mechanism of P3HT:bis-PC ${ }_{61}$ BM cells}

To investigate the degradation mechanism of P3HT:bis- $\mathrm{PC}_{61} \mathrm{BM}$ solar cells, the morphologies and absorption of the photoactive layers before and after aging were characterized and compared. Fig. S1a and b (ESI $\dagger$ ) show the 2D GIWAXS patterns of P3HT:bis$\mathrm{PC}_{61} \mathrm{BM}$ blend films before and after aging. The corresponding diffraction profiles along the in-plane $\left(q_{x y}\right)$ and out-of-plane $\left(q_{z}\right)$ directions are shown in Fig. S1c and d (ESI $\dagger$ ). As can be seen here, there is no obvious morphology change in the photoactive layers before and after aging, suggesting that the crystallinity and molecular stacking of P3HT:bis- $\mathrm{PC}_{61} \mathrm{BM}$ films hardly change during aging. Knowing that the formation of fullerene dimers would increase the absorption around $320 \mathrm{~nm},{ }^{20,21}$ we conducted UV-Vis characterization of the bis- $\mathrm{PC}_{61} \mathrm{BM}$ film exposed to continuous illumination for different hours. As can be seen from Fig. S2 (ESI $\dagger$ ), there is hardly a change in film absorption during continuous illumination, indicating that both the chemical components and crystalline structure of the blend film do not change significantly during aging. In other words, the degradation of devices cannot be attributed to the change in the nanomorphology of the photoactive layer.
To identify whether the top electrode $\left(\mathrm{MoO}_{3} / \mathrm{Al}\right)$ is the reason for the fast $V_{\mathrm{OC}}$ and $\mathrm{FF}$ decays of the solar cells, we then renewed the top electrodes $\left(\mathrm{MoO}_{3} / \mathrm{Al}\right)$ of the aged P3HT:bis$\mathrm{PC}_{61} \mathrm{BM}$ solar cells using a reported method. ${ }^{22}$ The top electrodes $\left(\mathrm{MoO}_{3} / \mathrm{Al}\right)$ of the aged devices were removed with a low concentration of sodium hydroxide solution and then the new top electrode $\left(\mathrm{MoO}_{3} / \mathrm{Al}\right)$ was redeposited. The $J-V$ curves, EQE spectra of pristine, aged and renewed $\mathrm{P} 3 \mathrm{HT}$ :bis- $\mathrm{PC}_{61} \mathrm{BM}$ solar cells with renewed $\mathrm{MoO}_{3} /$ $\mathrm{Al}$ electrodes are shown in Fig. 4. The corresponding photovoltaic performance data are summarized in Table 2. As seen here, the $V_{\mathrm{OC}}$ and $\mathrm{FF}$ of aged $\mathrm{P} 3 \mathrm{HT}$ :bis- $\mathrm{PC}_{61} \mathrm{BM}$ solar cells are recovered after renewing the $\mathrm{MoO}_{3} / \mathrm{Al}$ electrode. $\mathrm{A} V_{\mathrm{OC}}$ of $0.70 \mathrm{~V}$ and a $\mathrm{FF}$ of 0.52 are measured for the aged cells with the renewed $\mathrm{MoO}_{3} / \mathrm{Al}$ electrode, which correspond to $96 \%$ and $85 \%$ recovery of initial values, respectively, while $J_{\mathrm{SC}}$ is barely recovered. These results indicate that interfacial degradation should be one of the main reasons for the $V_{\mathrm{OC}}$ and FF decays of P3HT:bis- $\mathrm{PC}_{61} \mathrm{BM}$ solar cells. It is worth noting that the $J_{\mathrm{SC}}$ of the aged cells is not recovered over renewing the $\mathrm{MoO}_{3} / \mathrm{Al}$ electrode, suggesting other reasons causing the $J_{\mathrm{SC}}$ decay of the cell. Although the detailed reason for the $J_{\mathrm{SC}}$ decay is not fully understood yet, the normalized EQE spectra of the aged cells demonstrate that there should be other reasons related to the photoactive layer (Fig. 4b), not about the morphology but about the efficiency of photon-induced charge separation.

To further understand the detailed reason for interfacial degradation, XPS measurement was carried out on the model P3HT:bis- $\mathrm{PC}_{61} \mathrm{BM}(150 \mathrm{~nm}) / \mathrm{MoO}_{3}(5 \mathrm{~nm})$ films before and after illumination for 5 h. Fig. 5 shows the XPS spectra of the Mo $3 \mathrm{~d}$ core level for the pristine and illuminated films. For the fresh $\mathrm{MoO}_{3}$ films (Fig. 5a), the Mo 3d core level exhibits two symmetric peaks, centered at 232.9 and $236.0 \mathrm{eV}$, which can be attributed to the $3 \mathrm{~d}$ orbital doublet of $\mathrm{Mo}^{6+} \cdot{ }^{30,31}$ After light illumination for $5 \mathrm{~h}$, XPS peaks turn to be broader (Fig. $5 \mathrm{~b}$ ). By fitting of the peaks, 

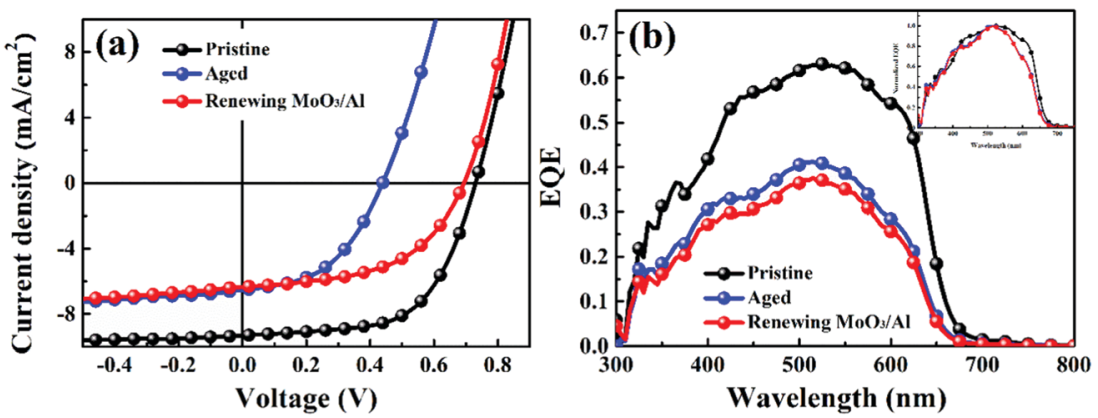

Fig. $4 \mathrm{~J}-V$ curves (a) and EQE spectra (b) of pristine, aged and renewed $\mathrm{P} 3 \mathrm{HT}$ :bis- $\mathrm{PC}_{61} \mathrm{BM}$ solar cells with new evaporated $\mathrm{MoO}{ }_{3} / \mathrm{Al}$ electrodes, the insert in (b) shows the normalized EQE spectra of these three cells, showing the changes of spectrum response for the aged cell.

Table 2 Photovoltaic parameters of pristine, aged and renewed $\mathrm{MoO}_{3} / \mathrm{Al}$ solar cells

\begin{tabular}{lllll}
\hline Entry & $J_{\mathrm{SC}}\left(\mathrm{mA} \cdot \mathrm{cm}^{2}\right)$ & $V_{\mathrm{OC}}(\mathrm{V})$ & FF & PCE $(\%)$ \\
\hline Pristine & 9.18 & 0.73 & 0.62 & $(0.61 \pm 0.016)$ \\
& $(9.14 \pm 0.11)$ & $(0.73 \pm 0.007)$ & 0.43 & $(4.07 \pm 0.17)$ \\
Aged & 6.63 & $(0.43 \pm 0.008)$ & $(0.46 \pm 0.006)$ & $(.37$ \\
& $(6.58 \pm 0.08)$ & 0.70 & 0.53 & $(1.31 \pm 0.04)$ \\
$\mathrm{New} \mathrm{MoO}_{3} / \mathrm{Al}$ & 6.34 & $(0.70 \pm 0.001)$ & $(0.52 \pm 0.008)$ & $(2.28 \pm 0.05)$ \\
& $(6.26 \pm 0.24)$ & & &
\end{tabular}
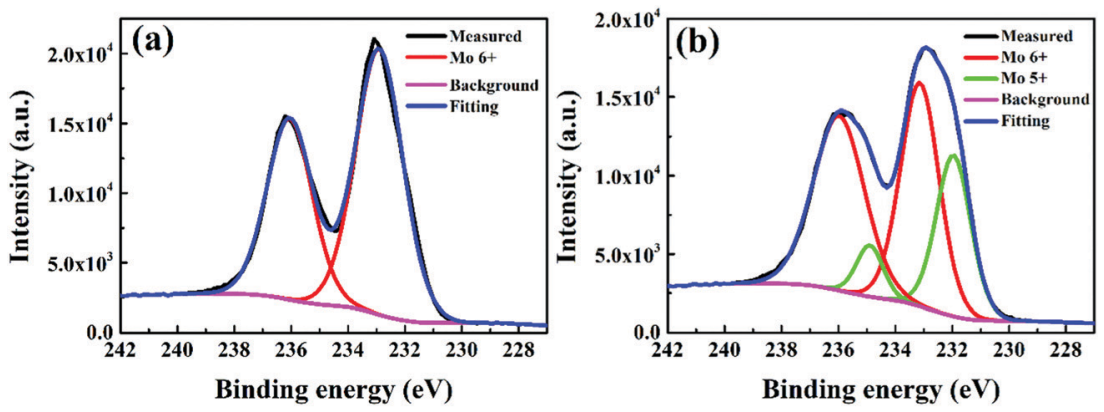

Fig. 5 XPS spectra of the Mo $3 \mathrm{~d}$ core level peaks for the $\mathrm{MoO}_{3}$ films deposited on P3HT:bis-PC ${ }_{61} \mathrm{BM}$ films before (a) and after (b) illumination for $5 \mathrm{~h}$.

two sets of peaks of 232.9/236.0 and 231.9/234.9 eV can be obtained, which are attributed to the $3 \mathrm{~d}$ doublets of $\mathrm{Mo}^{6+}$ and $\mathrm{Mo}^{5+}$, respectively. ${ }^{32}$ The results indicate that $\mathrm{Mo}^{6+}$ is partially reduced to $\mathrm{Mo}^{5+}$ under light illumination. Although the experimental result cannot define the reductant for the reduction of $\mathrm{Mo}^{6+}$ to $\mathrm{Mo}^{5+}$, it is supposed that P3HT must be the one since it has stronger electron donating capability than fullerene derivatives. As will be shown later (Section 3.3.1), the insertion of a thin $\mathrm{C}_{60}$ layer in P3HT:bis- $\mathrm{PC}_{61} \mathrm{BM}$ can substantially slow down the formation of $\mathrm{Mo}^{5+}$ and suppress the $V_{\mathrm{OC}}$ and $\mathrm{FF}$ decay (vide infra), which also support the speculation. Nevertheless, the experimental results confirm the occurrence of interfacial reduction of $\mathrm{Mo}^{6+}$ to $\mathrm{Mo}^{5+}$ under light illumination, which is supposed to be a detailed mechanism for the $V_{\mathrm{OC}}$ and FF degradation of the solar cells.

To identify whether the degradation of $\mathrm{MoO}_{3}$ occurs at the buried interface or at the top surface, we performed the angle resolved XPS (ARXPS) measurement on different P3HT:bis$\mathrm{PC}_{61} \mathrm{BM}$ films. By measuring the collected electrons at various emission angles, ARXPS measurement enables the detection of the elements' chemical information from different depths.
Fig. S3 in the ESI $\dagger$ shows the ARXPS spectra of the Mo 3d core level peaks for the freshly prepared and aged P3HT:bis- $\mathrm{PC}_{61} \mathrm{BM}$ $\mathrm{MoO}_{3}$ films. Since a slotted aperture is placed in front of the analyzer input lens as an angular filter, the measured ARXPS signal is weaker and noisier. As can be seen from Fig. S3(a) (ESI $\dagger$ ), the normalized XPS spectra of Mo 3d core level peaks measured from different angles of the pristine sample are identical. The Mo 3d core level exhibits two symmetric peaks, centered at 232.9 and $236.0 \mathrm{eV}$, which can be attributed to the $3 \mathrm{~d}$ orbital doublet of $\mathrm{Mo}^{6+}$. The results indicate that there is no significant difference for the $\mathrm{MoO}_{3}$ from the top surface to the buried interface. In contrast, as seen from Fig. S3(b) (ESI $\dagger$ ), the XPS spectra of Mo $3 \mathrm{~d}$ core level peaks of the aged sample gradually broaden with the increase of detection depth. The broadening of the XPS spectra is attributed to the formation of $\mathrm{Mo}^{5+}$ (vide supra). Therefore, the ARXPS results of the aged P3HT:bis- $\mathrm{PC}_{61} \mathrm{BM} / \mathrm{MoO}_{3}$ film indicate that the content of $\mathrm{Mo}^{5+}$ increases with the increase of detection depth. In other words, more $\mathrm{Mo}^{5+}$ was measured at the buried interface than at the top surface for the aged P3HT:bis- $\mathrm{PC}_{61} \mathrm{BM} / \mathrm{MoO}_{3}$ film. 


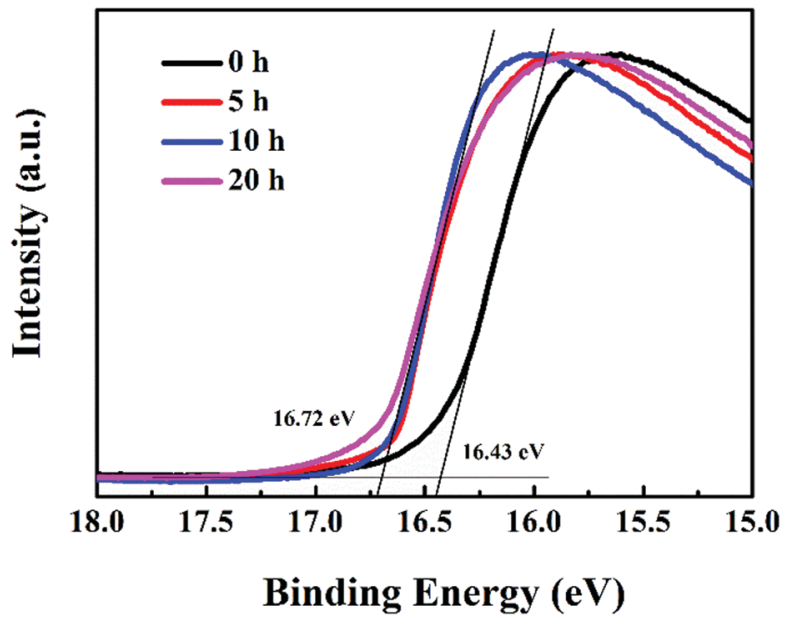

Fig. 6 UPS spectra of P3HT:bis- $\mathrm{PC}_{61} \mathrm{BM} / \mathrm{MoO}_{3}$ films before and after illumination for different times.

$\mathrm{MoO}_{3}$ is used as the hole transport layer to boost the charge transport efficiency of polymer solar cells, which has been ascribed to the formation of dipoles at the active layer $/ \mathrm{MoO}_{3}$ interface, based on the alignment of the highest occupied molecular orbital (HOMO) of the organic layer and the conduction band of $\mathrm{MoO}_{3}{ }^{33}$ The position of aligned energy levels can be estimated from the work function. ${ }^{34}$ In order to further understand the mechanism of device performance degradation caused by the reduction of $\mathrm{MoO}_{3}$, UPS spectra of P3HT:bis- $\mathrm{PC}_{61} \mathrm{BM} / \mathrm{MoO}_{3}$ films illuminated for different hours were tested, as shown in Fig. 6. Based on the UPS spectra, the work function of $\mathrm{MoO}_{3}$ films can be calculated. The results show that after illumination for more than 5 hours, the work function of $\mathrm{MoO}_{3}$ films decreased from 4.78 to $4.50 \mathrm{eV}$. Greiner et al. reported that the work functions of $\mathrm{MoO}_{3}$ tend to decrease with the decreasing cation oxidation state, ${ }^{35}$ which is consistent with the XPS (Fig. 5) and UPS (Fig. 6) results, and further confirms the reduction of $\mathrm{MoO}_{3}$. The decrease in the $\mathrm{MoO}_{3}$ work function indicates a decrease of the polarity of the surface of $\mathrm{MoO}_{3}$, this consequently decreases the dipole at the $\mathrm{P} 3 \mathrm{HT} / \mathrm{MoO}_{3}$ interface, and therefore decreases the charge transport over the interface. ${ }^{36}$ In that way, $\mathrm{Mo}^{6+}$ reduction to $\mathrm{Mo}^{5+}$ leads to fast $V_{\mathrm{OC}}$ and $\mathrm{FF}$ decays of devices, resulting in fast device performance degradation.

\subsection{Stability improvement of P3HT:bis- $\mathrm{PC}_{61} \mathrm{BM}^{\mathrm{B}}$ cells}

3.3.1 Stability improvement by inserting a thin $\mathrm{C}_{60}$ layer. To further confirm that interfacial photoreduction of $\mathrm{MoO}_{3}$ with P3HT is the reason for the fast $V_{\mathrm{OC}}$ and FF decays of the P3HT:bis- $\mathrm{PC}_{61} \mathrm{BM}$ cells, PSCs with an additional thin $\mathrm{C}_{60}$ layer (1.5-6 nm) between P3HT:bis- $\mathrm{PC}_{61} \mathrm{BM}$ and $\mathrm{MoO}_{3}$ were fabricated and tested. Fig. S4 (ESI $\dagger$ ) shows the UPS spectra of the P3HT:bis-PC ${ }_{61} \mathrm{BM}$ film before and after the deposition of a layer of $\mathrm{C}_{60}$. Based on the UPS, the HOMO level of films can be calculated. As can be seen here, after depositing a layer of $\mathrm{C}_{60}$ on the active layers, the HOMO level increased from 5.88 to $6.03 \mathrm{eV}$, which is close to the HOMO value of the $\mathrm{C}_{60}$ film reported in the literature. ${ }^{37}$ The UPS results confirmed that $\mathrm{C}_{60}$ does not intermix into the active layer, but deposits on the surface. Fig. S5 (ESI $\dagger$ ) shows the $J-V$ curves of $\mathrm{P} 3 \mathrm{HT}$ :bis- $\mathrm{PC}_{61} \mathrm{BM}$ solar cells with different thicknesses of $\mathrm{C}_{60}$, and the corresponding photovoltaic parameters are listed in Table S1 (ESI $\dagger$ ). As can be seen here, for the P3HT:bis- $\mathrm{PC}_{61} \mathrm{BM}$ solar cells with $1.5-3 \mathrm{~nm}$ of $\mathrm{C}_{60}$ layer, comparable device performance $(\sim 4.07 \%)$ to that of the device without $\mathrm{C}_{60}(4.17 \%)$ is obtained, indicating that a thin $\mathrm{C}_{60}$ layer does not influence the device performance too much. Increasing the thickness of the $\mathrm{C}_{60}$ layer to 4.5-6.0 $\mathrm{nm}$ lowers the device performance, which could be due to the hole blocking property of the bis- $\mathrm{PC}_{61} \mathrm{BM}$ layer for its deep HOMO energy level.

Fig. 7 depicts the evolution of $V_{\mathrm{OC}}, J_{\mathrm{SC}}, \mathrm{FF}$ and PCE of the P3HT:bis-PC ${ }_{61} \mathrm{BM}$ solar cells with different $\mathrm{C}_{60}$ layers aged at mpp with continuous light illumination. As can be seen here, the pristine $\mathrm{P} 3 \mathrm{HT}$ :bis- $\mathrm{PC}_{61} \mathrm{BM}$ cells undergo a fast "burn-in" degradation over $200 \mathrm{~h}$, with a fast $V_{\mathrm{OC}}$ decay of $24 \%, J_{\mathrm{SC}}$ decay of $19 \%$ and $\mathrm{FF}$ decay of $14 \%$. In contrast, P3HT:bis-PC ${ }_{61} \mathrm{BM}$ solar cells inserted with $3 \mathrm{~nm}$ of $\mathrm{C}_{60}$ layer show an overall $28 \%$ PCE degradation, with only $5 \% V_{\mathrm{OC}}$ decay, $17 \% J_{\mathrm{SC}}$ decay and $7 \% \mathrm{FF}$ decay. Obviously, the insertion of the $\mathrm{C}_{60}$ layer greatly improves the stability of $V_{\mathrm{OC}}$ and FF of P3HT:bis- $\mathrm{PC}_{61} \mathrm{BM}$ solar cells. This can be understood by the fact that the insertion of the $\mathrm{C}_{60}$ layer reduces the contact of $\mathrm{P} 3 \mathrm{HT}$ and $\mathrm{MoO}_{3}$, resulting in the inhibition of their reaction and thus improving the stability of devices. These results not only confirm that the interface degradation is the main factor of $V_{\mathrm{OC}}$ and FF decays of P3HT:bis-PC ${ }_{61} \mathrm{BM}$ solar cells, but also provide an effective way to improve the stability of $V_{\mathrm{OC}}$ and $\mathrm{FF}$ of different types of polymer solar cells.

3.3.2 Stability improvement by piperazine doping. Although depositing a thin layer of $\mathrm{C}_{60}$ on the surface of the active layer can suppress the reaction between $\mathrm{P} 3 \mathrm{HT}$ and $\mathrm{MoO}_{3}$, the complex evaporation process is not conducive to large-area printing preparation. Our previous works have demonstrated that piperazine is able to stabilize the $\mathrm{P} 3 \mathrm{HT}: \mathrm{PC}_{61} \mathrm{BM}$ cells through the blocking of the photodimerization process. ${ }^{23}$ Our latest results confirmed also that piperazine is able to form hydrogen bonds with fullerene molecules. ${ }^{38}$ It is supposed that doping the photoactive layer with piperazine might be able to tune the vertical phase separation of the photoactive layer owing to the volatility of piperazine and the capability of forming hydrogen bonding with fullerene molecules. We then fabricated piperazine doped P3HT:bis- $\mathrm{PC}_{61} \mathrm{BM}$ films, and checked the nanomorphology and surface component of these films. Fig. 8 shows the AFM images of the P3HT:bis- $\mathrm{PC}_{61} \mathrm{BM}$ films doped with different piperazine concentration. The root mean surface roughness (RMS) of these films is measured to be 6.13, 6.88, 8.79 and $8.47 \mathrm{~nm}$ for P3HT:bis-PC ${ }_{61} \mathrm{BM}$ blend films doped with $0 \%, 0.5 \%, 1 \%$ and $5 \%$ of piperazine, respectively, indicating that piperazine doping is able to tune the nanomorphology of the P3HT:bis-PC ${ }_{61} \mathrm{BM}$ film.

Then XPS characterization was performed to characterize the surface components of the P3HT:bis- $\mathrm{PC}_{61} \mathrm{BM}$ film with piperazine doping. Fig. S6 (ESI $\dagger$ ) shows the XPS spectra of $\mathrm{C}$ 1s and $\mathrm{S} 2 \mathrm{p}$ of P3HT:bis- $\mathrm{PC}_{61} \mathrm{BM}$ blend films with different concentrations of piperazine. As seen here, the $\mathrm{C} 1 \mathrm{~s}$ peak can be 

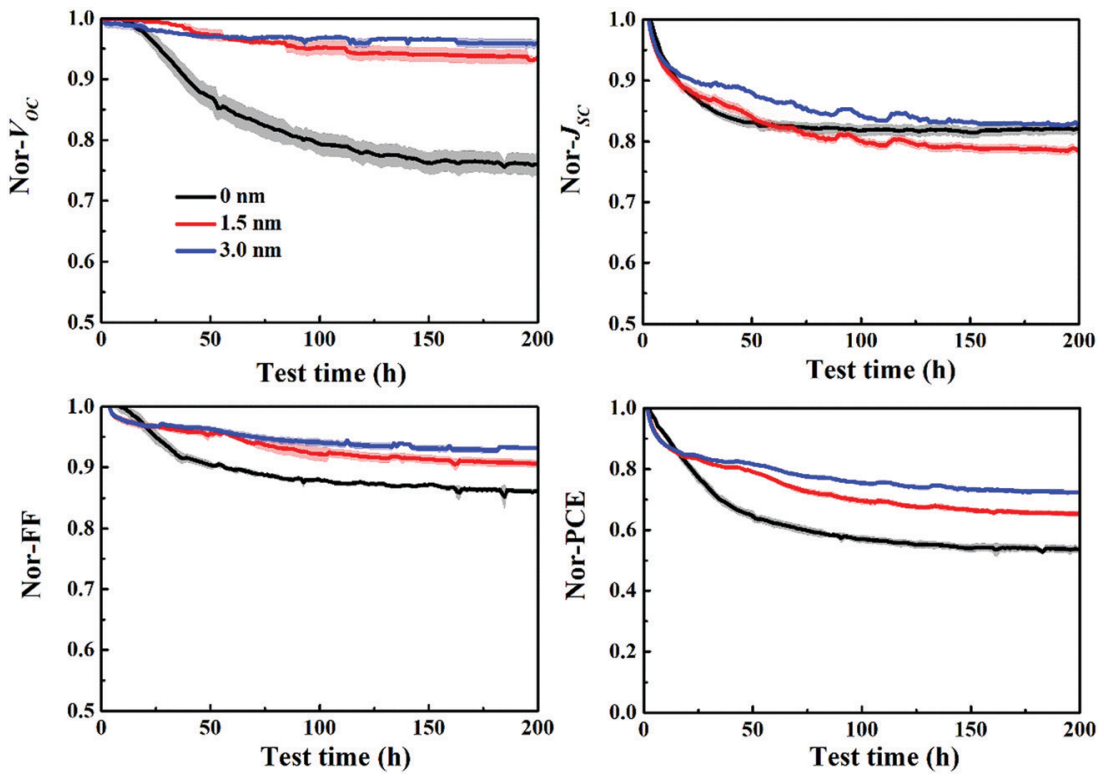

Fig. 7 Evolution of $V_{O C}, J_{S C}, F F$ and PCE of ITO/ZnO/P3HT:bis- $\mathrm{PC}_{61} \mathrm{BM} / \mathrm{C}_{60}(0-3 \mathrm{~nm}) / \mathrm{MoO}_{3} / \mathrm{Al}$ solar cells aged at mpp with continuous light illumination.
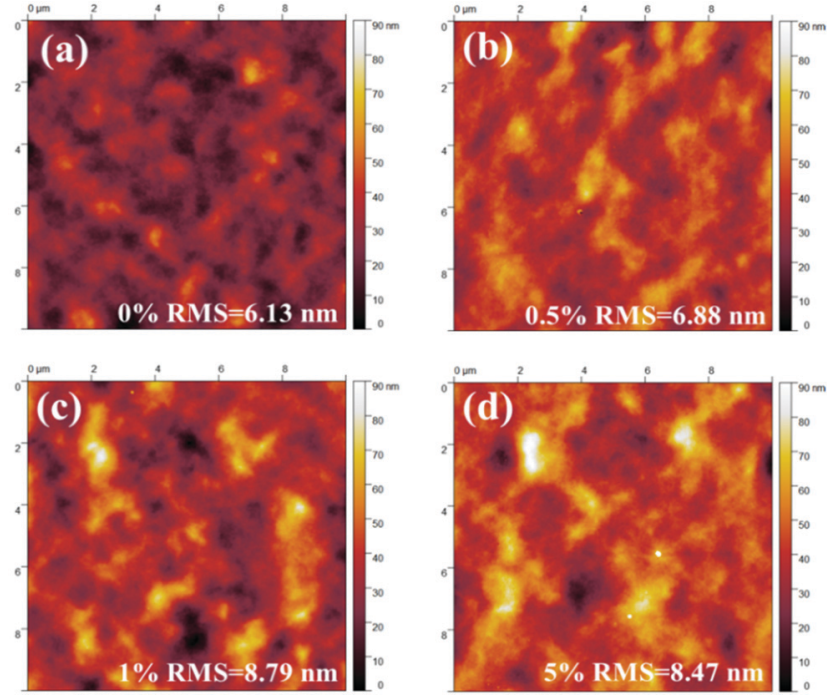

Fig. 8 AFM images of P3HT:bis- $\mathrm{PC}_{61} \mathrm{BM}$ blend films with different concentrations of piperazine. fitted into two components, corresponding to $\mathrm{C}-\mathrm{C}$ at $284.78 \mathrm{eV}$ and $\mathrm{C}-\mathrm{O}$ at $285.91 \mathrm{eV},{ }^{39}$ where the $\mathrm{C}-\mathrm{O}$ signal can be assigned to the component of bis- $\mathrm{PC}_{61} \mathrm{BM}$. Fig. 9 shows the fitted results of $\mathrm{C}-\mathrm{C}$ and $\mathrm{C}-\mathrm{O}$. The $\mathrm{C}-\mathrm{O} / \mathrm{C}-\mathrm{C}$ ratios for these films were calculated from the overall area ratio of $\mathrm{C} 1 \mathrm{~s}(\mathrm{C}-\mathrm{O})$ and $\mathrm{C}$ $1 \mathrm{~s}(\mathrm{C}-\mathrm{C})$ XPS signals, and the results are listed in Table 3. As seen here, doping the blend film with piperazine increases the $\mathrm{C}-\mathrm{O} / \mathrm{C}-\mathrm{C}$ ratio from 0.27 to $0.29-0.30$, suggesting slightly higher bis- $\mathrm{PC}_{61} \mathrm{BM}$ content after piperazine doping.

Similarly, the $S 2 \mathrm{p}$ peak can also be fitted with two peaks centering at 164.98 and $163.73 \mathrm{eV}$, which can be attributed to the spin-orbit splitting doublet $S 2 \mathrm{p}_{1 / 2}$ and $\mathrm{S} 2 \mathrm{p}_{3 / 2}$, respectively. ${ }^{40}$ The $\mathrm{C} / \mathrm{S}$ ratios for these films are then calculated from the overall area ratio of $\mathrm{C} 1 \mathrm{~s}$ and $\mathrm{S} 2 \mathrm{p}$ signals, taking into account the relative sensitivity factors (RSF): ${ }^{41}$

$$
\mathrm{C} / \mathrm{S}=\frac{A_{\mathrm{C} 1 \mathrm{~s}}}{A_{\mathrm{S} 2 \mathrm{p}}} \cdot \frac{\operatorname{RSF}(\mathrm{S} 2 \mathrm{p})}{\operatorname{RSF}(\mathrm{C} 1 \mathrm{~s})}
$$

where $A_{\mathrm{C} 1 \mathrm{~s}}$ and $A_{\mathrm{S} 2 \mathrm{p}}$ are the overall area of $\mathrm{C} 1 \mathrm{~s}$ and $\mathrm{S} 2 \mathrm{p}$ signals, respectively, $\operatorname{RSF}(\mathrm{S} 2 \mathrm{p})=54.797$ and $\operatorname{RSF}(\mathrm{C} 1 \mathrm{~s})=21.138$ are (a)

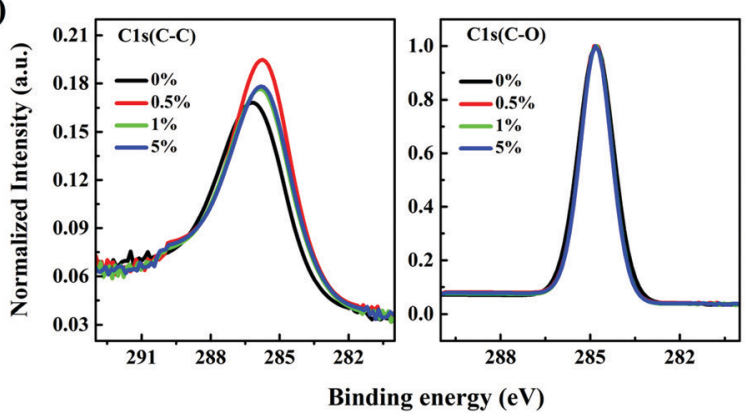

(b)

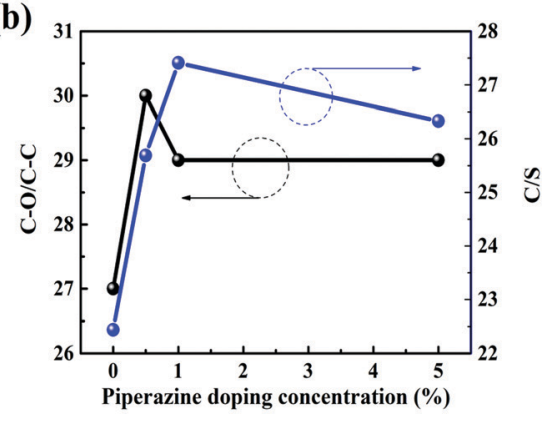

Fig. 9 Normalized XPS spectra of $\mathrm{C}$ 1s of P3HT:bis- $\mathrm{PC}_{61} \mathrm{BM}$ blend films with different concentrations (0-5\%) of piperazine. 
Table $3 \mathrm{C}-\mathrm{O} / \mathrm{C}-\mathrm{C}$ ratio, $\mathrm{C} / \mathrm{S}$ ratio and bis- $\mathrm{PC}_{61} \mathrm{BM} / 3$-hexylthiophene molecular ratio determined by the deconvolution of $C 1 s$ and $S 2 p$ XPS spectra for $\mathrm{P} 3 \mathrm{HT}$ :bis- $\mathrm{PC}_{61} \mathrm{BM}$ blend films with different piperazine doping concentrations

\begin{tabular}{llll}
\hline $\begin{array}{l}\text { Piperazine } \\
\text { doping ratio (\%) }\end{array}$ & $\mathrm{C}-\mathrm{O} / \mathrm{C}-\mathrm{C}$ & $\mathrm{C} / \mathrm{S}$ & $\begin{array}{l}\text { Bis-PC }{ }_{61} \mathrm{BM} / 3-\mathrm{h} \text {-xyl- } \\
\text { thiophene ratio }\end{array}$ \\
\hline 0 & $0.27 \pm 0.011$ & $22.44 \pm 1.05$ & 0.148 \\
0.5 & $0.30 \pm 0.017$ & $25.69 \pm 0.71$ & 0.187 \\
1 & $0.29 \pm 0.016$ & $27.41 \pm 0.06$ & 0.207 \\
5 & $0.29 \pm 0.003$ & $26.33 \pm 0.40$ & 0.194
\end{tabular}

determined by X-ray photoelectron spectroscopy. The molecular ratio of bis- $\mathrm{PC}_{61} \mathrm{BM}$ to the 3-hexylthiophene unit (corresponding to P3HT content) on the surface of the photoactive layer is then calculated based on their molecular weights and $\mathrm{C} / \mathrm{S}$ ratios. The results are summarized in Table 3 . The pristine composite film exhibits a $\mathrm{C} / \mathrm{S}$ ratio of 22.44 and a bis- $\mathrm{PC}_{61} \mathrm{BM} / 3$-hexylthiophene molecular ratio of 0.148 . Not surprisingly, the piperazine doping significantly increases the $\mathrm{C} / \mathrm{S}$ ratio $(25.69-27.41)$ and the corresponding bis- $\mathrm{PC}_{61} \mathrm{BM} / 3$-hexylthiophene molecular ratio (0.187-0.207), suggesting the increase of bis- $\mathrm{PC}_{61} \mathrm{BM}$ content on the blend film surface, in good accordance with the increase of the above-mentioned $\mathrm{C}-\mathrm{O} / \mathrm{C}-\mathrm{C}$ ratio.

UPS characterization of P3HT:bis- $\mathrm{PC}_{61} \mathrm{BM}$ blend films with different piperazine doping concentrations was performed further to investigate the migration of bis- $\mathrm{PC}_{61} \mathrm{BM}$ in the active layer, and the results are shown in Fig. S7 (ESI $\dagger$ ). The results show that the HOMO of films increased from 5.75 to $5.90 \mathrm{eV}$ after doping with piperazine. The HOMO levels of P3HT and bis$\mathrm{PC}_{61} \mathrm{BM}$ were reported to be $4.77 \mathrm{eV}^{26}$ and $6.10 \mathrm{eV},{ }^{13}$ respectively. Therefore, the increase of the HOMO level on the surface of the film indicates that bis- $\mathrm{PC}_{61} \mathrm{BM}$ has undergone an upward migration in the active layer with the doping of piperazine.

Then, the piperazine doped P3HT:bis- $\mathrm{PC}_{61} \mathrm{BM}$ solar cells were fabricated, and their photovoltaic performance and stability were tested. Fig. 10 shows the $J-V$ curves and EQE spectra of P3HT:bis-PC ${ }_{61} \mathrm{BM}$ solar cells doped with piperazine, and the corresponding photovoltaic parameters are listed in Table 4. As can be seen here, the pristine $\mathrm{P} 3 \mathrm{HT}$ :bis- $\mathrm{PC}_{61} \mathrm{BM}$ cells show a PCE of $4.07 \%$. Doping piperazine into the photoactive layer significantly increases the PCE, and the highest PCE of $4.81 \%$ is achieved for the $5 \%$ piperazine doped cells. Such a performance enhancement is due to the large increase in the $\mathrm{FF}$ value
Table 4 Photovoltaic parameters of P3HT:bis- $\mathrm{PC}_{61} \mathrm{BM}$ cells with piperazine doping concentrations of $0-10 \%$

\section{Piperazine}

doping

concentration

\begin{tabular}{lllll}
$(\%)$ & $J_{\text {SC }}\left(\mathrm{mA} \mathrm{cm}^{2}\right)$ & $V_{\text {OC }}(\mathrm{V})$ & FF & PCE $(\%)$ \\
\hline 0 & 9.18 & 0.730 & 0.62 & 4.09 \\
& $(9.10 \pm 0.10)(0.728 \pm 0.008)(0.61 \pm 0.005)$ & $(4.07 \pm 0.17)$ \\
0.5 & 9.28 & 0.733 & 0.67 & 4.56 \\
& $(9.23 \pm 0.09)(0.731 \pm 0.004)(0.66 \pm 0.008)$ & $(4.45 \pm 0.12)$ \\
1 & 9.47 & 0.733 & 0.66 & 4.58 \\
& $(9.40 \pm 0.08)(0.729 \pm 0.005)(0.65 \pm 0.006)$ & $(4.45 \pm 0.17)$ \\
5 & 9.63 & 0.735 & 0.68 & 4.81 \\
& $(9.59 \pm 0.13)(0.732 \pm 0.003)(0.67 \pm 0.01)$ & $(4.71 \pm 0.09)$ \\
10 & 9.67 & 0.730 & 0.65 & 4.59 \\
& $(9.59 \pm 0.13)(0.727 \pm 0.004)(0.64 \pm 0.006)$ & $(4.46 \pm 0.13)$
\end{tabular}

and the slight increase in $V_{\mathrm{OC}}$ and $J_{\mathrm{SC}}$ values. In our previous work we confirmed that the intermolecular electron transfer between piperazine and fullerene molecules leads to n-doping of fullerene domains and consequently improves the electron mobility of the blend films, ${ }^{23}$ which should be the main reason for the $J_{\mathrm{SC}}$ increase of the piperazine doped devices. However, the increased $\mathrm{FF}$ might be ascribed to the improvement of interface contact between the active layer and electrodes, which is confirmed by the AFM results (Fig. 8). It is worth highlighting that even at a high doping concentration of $10 \%$, the device performance $(4.59 \%)$ is still higher than that $(4.09 \%)$ of the pristine cell. These results fully confirm that piperazine doping can also improve the device performance of P3HT:bis- $\mathrm{PC}_{61} \mathrm{BM}$ solar cells.

The stability of P3HT:bis-PC ${ }_{61} \mathrm{BM}$ solar cells with different concentrations of piperazine was further investigated, as shown in Fig. 11. The results show that the stability of piperazine doped solar cells increases significantly as expected, which is mainly due to the improved $V_{\mathrm{OC}}$ and $\mathrm{FF}$ stability. When doped with $0.5 \%$ piperazine, P3HT:bis- $\mathrm{PC}_{61} \mathrm{BM}$ solar cells show almost no decay in $V_{\mathrm{OC}}$ and $\mathrm{FF}$, and slightly improved stability of $J_{\mathrm{SC}}$, which results in great stability improvement of device PCE. Given that bis- $\mathrm{PC}_{61} \mathrm{BM}$ is not prone to dimerization, ${ }^{20}$ the stability enhancement mechanism of piperazine doping is not dimerization inhibition, which can be confirmed by little improvement in $J_{\mathrm{SC}}$. Therefore, the stability improvement of P3HT:bis- $\mathrm{PC}_{61} \mathrm{BM}$ solar cells by piperazine doping is then ascribed to the increase of the bis$\mathrm{PC}_{61} \mathrm{BM}$ component on the surface of active layers, which suppresses the interfacial photoreduction of $\mathrm{MoO}_{3}$.
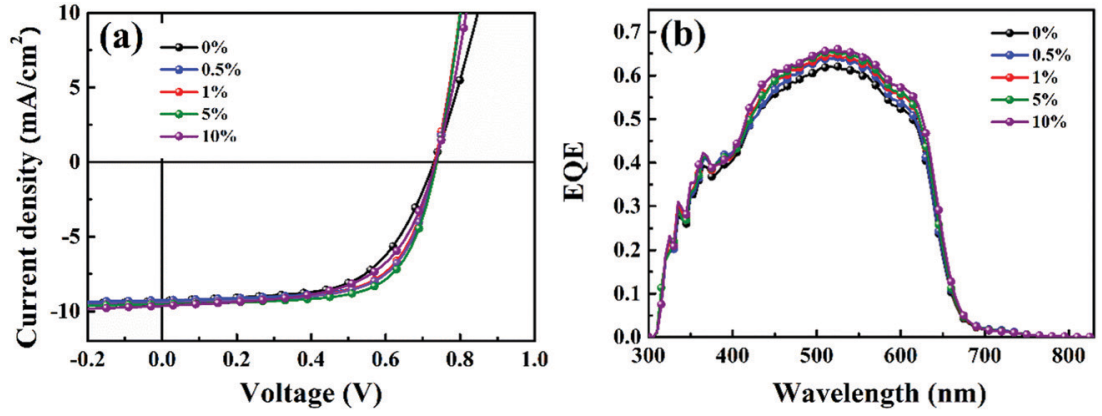

Fig. $10 \mathrm{~J}-V$ curves (a) and EQE spectra (b) of $\mathrm{P} 3 \mathrm{HT}$ :bis- $\mathrm{PC}_{61} \mathrm{BM}$ cells with piperazine doping concentrations of $0-10 \%$. 

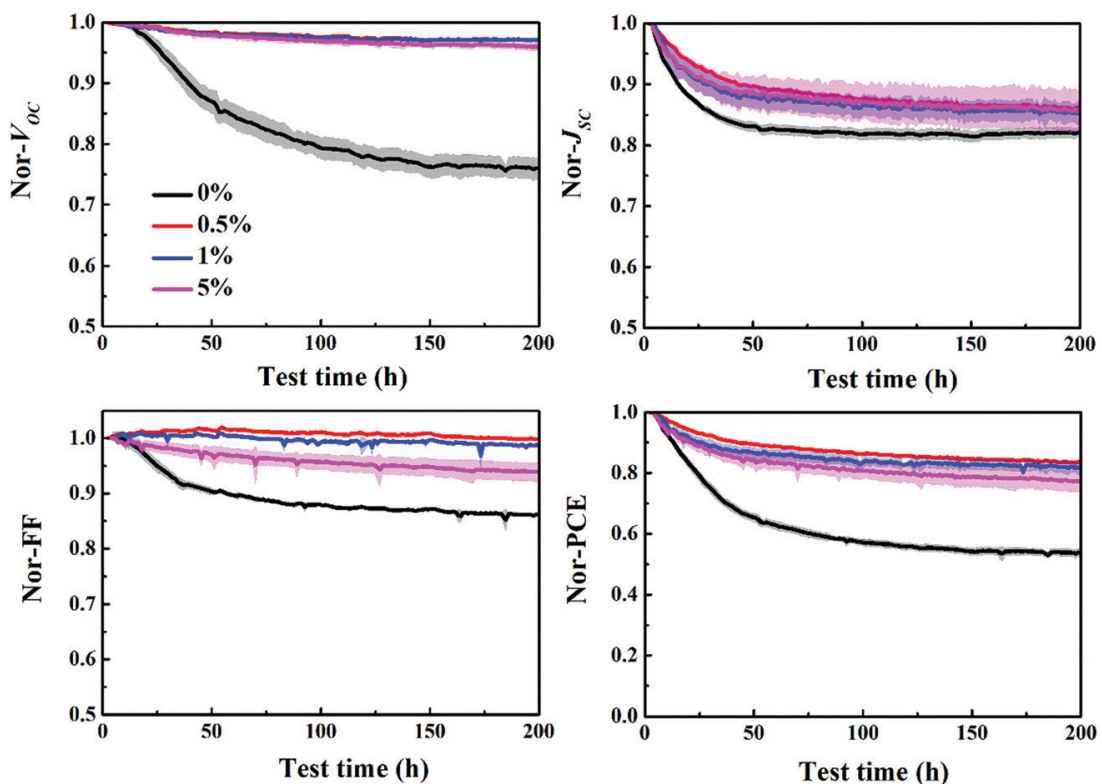

Fig. 11 Evolution of the $V_{\mathrm{OC}}, J_{\mathrm{SC}}, \mathrm{FF}$ and $\mathrm{PCE}$ of $\mathrm{P} 3 \mathrm{HT}$ :bis- $\mathrm{PC}{ }_{61} \mathrm{BM}$ cells with piperazine doping concentrations of $0-5 \%$ aged at mpp with continuous light illumination.

3.3.3 Suppressing $\mathrm{Mo}^{6+}$ reduction by piperazine doping and $\mathbf{C}_{60}$ insertion. To further confirm that insertion of the $\mathrm{C}_{60}$ layer and doping of piperazine are able to suppress the reduction of $\mathrm{MoO}_{3}$, P3HT:bis-PC ${ }_{61} \mathrm{BM} / \mathrm{MoO}_{3}$, P3HT:bis- $\mathrm{PC}_{61} \mathrm{BM} / \mathrm{C}_{60} / \mathrm{MoO}_{3}$ and P3HT:bis- $\mathrm{PC}_{61} \mathrm{BM}$ :piperazine $/ \mathrm{MoO}_{3}$ films were prepared and aged under light illumination for $5 \mathrm{~h}$, and then checked with XPS (Fig. 5 and Fig. S8, ESI $\dagger$ ). Fig. 12 displays the normalized XPS spectra of these films in comparison with the pristine reference film. As seen here, after light illumination, all these films show the broadening of XPS peaks, indicating the formation of $\mathrm{Mo}^{5+}$ during light illumination. The $\mathrm{Mo}^{6+} / \mathrm{Mo}^{5+}$ ratio of $\mathrm{MoO}_{3}$ films was determined by deconvolution of $\mathrm{Mo}^{6+}$ and $\mathrm{Mo}^{5+}$ XPS spectra, and the results are listed in Fig. 12. As seen here, both $\mathrm{C}_{60}$ insertion and piperazine doping increase the $\mathrm{Mo}^{6+} / \mathrm{Mo}^{5+}$ ratio (3.58:1 and 3.52:1) of $\mathrm{MoO}_{3}$ films in comparison with the aged bare P3HT:bis- $\mathrm{PC}_{61} \mathrm{BM}$ film (2.42:1), indicating that both methods inhibit the reduction of $\mathrm{MoO}_{3}$, again supporting the proposed degradation mechanism of this class of cells. Furthermore, ARXPS characterization of P3HT:bis- $\mathrm{PC}_{61} \mathrm{BM} / \mathrm{C}_{60} / \mathrm{MoO}_{3}$ and
P3HT:bis- $\mathrm{PC}_{61} \mathrm{BM}$ :piperazine $/ \mathrm{MoO}_{3}$ films was also conducted, and the results are shown in Fig. S3(c) and (d) in the ESI. $\dagger$ Based on the ARXPS spectra, the $\mathrm{Mo}^{6+} / \mathrm{Mo}^{5+}$ ratios of the aged P3HT:bis$\mathrm{PC}_{61} \mathrm{BM} / \mathrm{MoO}_{3}$, P3HT:bis-PC ${ }_{61} \mathrm{BM}$ :piperazine $/ \mathrm{MoO}_{3}$ and P3HT:bis$\mathrm{PC}_{61} \mathrm{BM} / \mathrm{C}_{60} / \mathrm{MoO}_{3}$ films were calculated. As seen from these figures, the P3HT:bis- $\mathrm{PC}_{61} \mathrm{BM} / \mathrm{MoO}_{3}$ films with the $\mathrm{C}_{60}$ interlayer or doped with piperazine also showed broader XPS spectra with the increase of the detection depth, indicating the formation of $\mathrm{Mo}^{5+}$ at the buried interface after aging. The $\mathrm{Mo}^{5+} / \mathrm{Mo}^{6+}$ ratio calculated from the XPS spectrum is then plotted versus the ARXPS emission angle, and the results are shown in Fig. 12(b). As clearly shown here, the sample with the $\mathrm{C}_{60}$ interlayer or doped with piperazine showed a lower $\mathrm{Mo}^{5+} / \mathrm{Mo}^{6+}$ ratio at large emission angle, indicating that $\mathrm{C}_{60}$ insertion and piperazine doping have an inhibitory effect on the reduction of $\mathrm{Mo}^{6+}$. These results correspond very well to the stabilization effect of the $\mathrm{C}_{60}$ layer and the doping with piperazine in the solar cells (vide supra), confirming that the reduction of $\mathrm{MoO}_{3}$ by the p-type polymer should be one of the main reasons for the fast $V_{\mathrm{OC}}$ and FF decays of the solar cells.
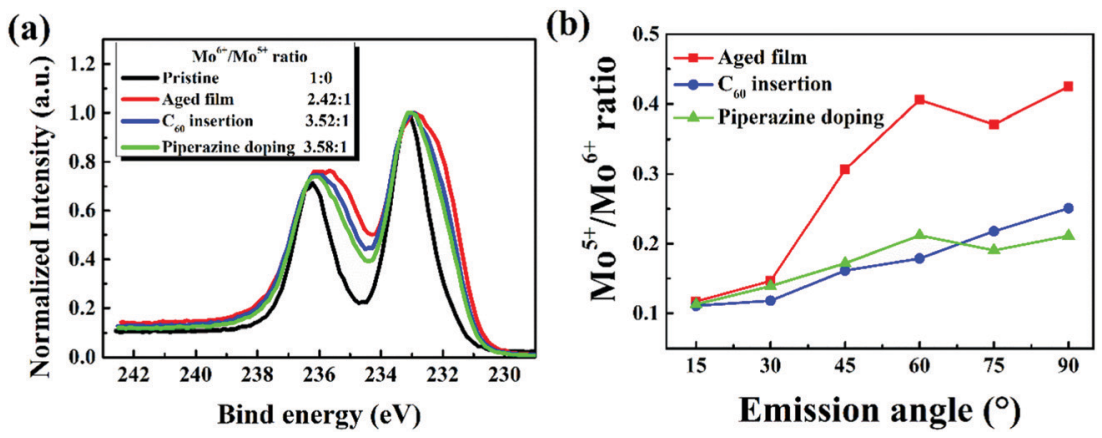

Fig. 12 XPS spectra of the Mo $3 \mathrm{~d}$ core level peaks (a) and $\mathrm{Mo}^{6+} / \mathrm{Mo}^{5+}$ ratio plotted versus ARXPS emission angle (b) for the $\mathrm{P} 3 \mathrm{HT}$ :bis- $\mathrm{PC}_{61} \mathrm{BM}^{\mathrm{B}} \mathrm{MoO} \mathrm{O}_{3}$ films, $\mathrm{P} 3 \mathrm{HT}$ :bis- $\mathrm{PC}_{61} \mathrm{BM}$ :piperazine $/ \mathrm{MoO}_{3}$ and $\mathrm{P} 3 \mathrm{HT}$ :bis- $-\mathrm{PC}_{61} \mathrm{BM} / \mathrm{C}_{60} / \mathrm{MoO}_{3}$ films after illumination for $5 \mathrm{~h}$. 

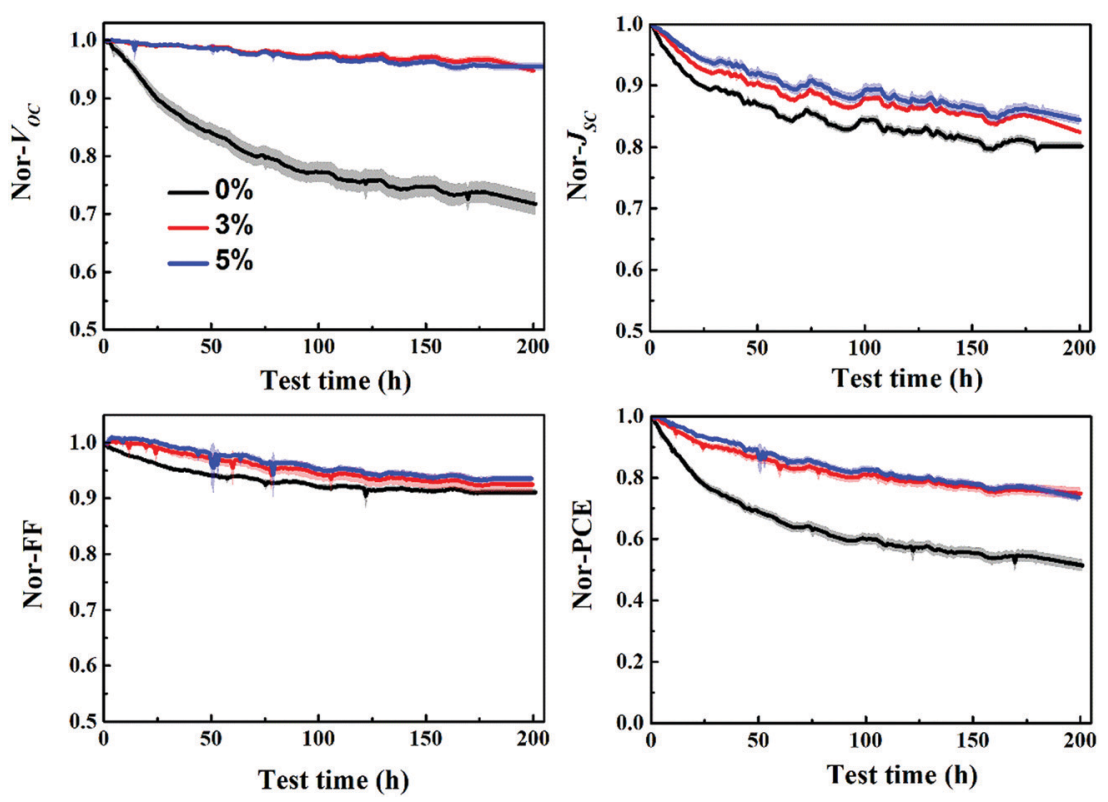

Fig. 13 Evolution of the $V_{\mathrm{OC}}, J_{\mathrm{SC}}$ FF and PCE of P3HT:ICBA cells with piperazine doping concentrations of $0-5 \%$ aged at mpp with continuous light illumination.

\subsection{Stability improvement by piperazine doping in P3HT:ICBA solar cells}

To confirm the generality of piperazine doping in improving the $V_{\mathrm{OC}}$ and FF stability of polymer:fullerene bis-adduct solar cells, piperazine doped P3HT:ICBA solar cells were fabricated and tested. Fig. S9 (ESI $\dagger$ ) shows the $J-V$ and EQE spectra of the P3HT:ICBA cells with different piperazine doping concentrations and the photovoltaic performance data are listed in Table S2 (ESI $\dagger$ ). Again, doping P3HT:ICBA with piperazine increases the device performance, and the highest PCE of $5.72 \%$ is achieved for the $5 \%$ piperazine doped cell, confirming the generality of piperazine doping in performance improvement. More importantly, piperazine doping can also improve the stability of P3HT:ICBA solar cells (Fig. 13), demonstrating the generality of $V_{\mathrm{OC}}$ and FF degradation suppression effects of piperazine doping.

\section{Conclusions}

In conclusion, the polymer:fullerene bis-adduct (bis- $\mathrm{PC}_{61} \mathrm{BM}$ and ICBA) based solar cells demonstrate a fast "burn-in" degradation under light illumination, where $V_{\mathrm{OC}}$ and $\mathrm{FF}$ decays are quite significant to the overall performance degradation when compared to the $\mathrm{PC}_{61} \mathrm{BM}$ based cells. The recovery of $V_{\mathrm{OC}}$ and $\mathrm{FF}$ of the cell by renewing the $\mathrm{MoO}_{3} / \mathrm{Al}$ electrode of the aged cell indicates that the interfacial degradation at the photoactive layer and $\mathrm{MoO}_{3}$ could be the main reason for $V_{\mathrm{OC}}$ and $\mathrm{FF}$ decays. XPS analysis of the P3HT:bis- $\mathrm{PC}_{61} \mathrm{BM} / \mathrm{MoO}_{3}$ films confirms the reduction of $\mathrm{Mo}^{6+}$ to $\mathrm{Mo}^{5+}$. Inserting a thin layer of $\mathrm{C}_{60}$ between the photoactive layer and $\mathrm{MoO}_{3}$ can suppress the reduction of $\mathrm{Mo}^{6+}$ and slower the $V_{\mathrm{OC}}$ decay. Therefore a photo-induced reduction of $\mathrm{Mo}^{6+}$ to $\mathrm{Mo}^{5+}$ by P3HT is supposed to be the detailed mechanism for the $V_{\mathrm{OC}}$ and FF decays of polymer:fullerene bis-adduct solar cells. In addition, piperazine doping within the P3HT:fullerene bis-adduct film increases the fullerene content on the surface of the photoactive layer, which consequently improved device stability. The current work reveals the interfacial degradation mechanism of PSCs, and provides effective solutions for stability improvement, which will guide in improving the stability of different types of polymer solar cells.

\section{Conflicts of interest}

There are no conflicts to declare.

\section{Acknowledgements}

The authors would like to acknowledge the financial support from the Ministry of Science and Technology of China (No. 2016YFA0200700), the Chinese Academy of Science (No. YJKYYQ20180029 and CAS-ITRI 2019010), the National Natural Science Foundation of China (61904121), the Youth Innovation Promotion Association, CAS (2019317), and the Natural Science Foundation of Shanxi Province (201801D221136). Thanks are also due to the support from the Suzhou Vacuum Interconnected Nanotechnology Workstation H005-2019 project.

\section{Notes and references}

1 Y. Lin, B. Adilbekova, Y. Firdaus, E. Yengel, H. Faber, M. Sajjad, X. Zheng, E. Yarali, A. Seitkhan, O. M. Bakr, A. El-Labban, U. Schwingenschlögl, V. Tung, I. McCulloch, F. Laquai and T. D. Anthopoulos, Adv. Mater., 2019, 31, 1902965.

2 L. X. Meng, Y. M. Zhang, X. J. Wan, C. X. Li, X. Zhang, Y. B. Wang, X. Ke, Z. Xiao, L. M. Ding, R. X. Xia, H. L. Yip, Y. Cao and Y. S. Chen, Science, 2018, 361, 1094-1098. 
3 https:/www.nrel.gov/pv/assets/pdfs/champion-module-efficiencies. 20191104.pdf.

4 J. B. Zhao, Y. K. Li, G. F. Yang, K. Jiang, H. R. Lin, H. Ade, W. Ma and H. Yan, Nat. Energy, 2016, 1, 15027.

5 J. Huang, J. H. Carpenter, C. Z. Li, J. S. Yu, H. Ade and A. K. Y. Jen, Adv. Mater., 2016, 28, 967-974.

6 J. You, L. Dou, K. Yoshimura, T. Kato, K. Ohya, T. Moriarty, K. Emery, C.-C. Chen, J. Gao, G. Li and Y. Yang, Nat. Commun., 2013, 4, 1446.

7 Y. Sun, M. Chang, L. Meng, X. Wan, H. Gao, Y. Zhang, K. Zhao, Z. Sun, C. Li, S. Liu, H. Wang, J. Liang and Y. Chen, Nat. Electron., 2019, 2, 513-520.

8 B. Fan, Z. Zeng, W. Zhong, L. Ying, D. Zhang, M. Li, F. Peng, N. Li, F. Huang and Y. Cao, ACS Energy Lett., 2019, 4, 2466-2472.

9 W. C. Zhao, S. S. Li, S. Q. Zhang, X. Y. Liu and J. H. Hou, Adv. Mater., 2017, 29, 1604059.

10 M. T. Dang, L. Hirsch and G. Wantz, Adv. Mater., 2011, 23, 3597-3602.

11 S. H. Park, A. Roy, S. Beaupre, S. Cho, N. Coates, J. S. Moon, D. Moses, M. Leclerc, K. Lee and A. J. Heeger, Nat. Photonics, 2009, 3, 297-302.

12 S.-H. Liao, H.-J. Jhuo, Y.-S. Cheng and S.-A. Chen, Adv. Mater., 2013, 25, 4766-4771.

13 L. Ye, S. Zhang, D. Qian, Q. Wang and J. Hou, J. Phys. Chem. C, 2013, 117, 25360-25366.

14 M. Lenes, G. J. A. H. Wetzelaer, F. B. Kooistra, S. C. Veenstra, J. C. Hummelen and P. W. M. Blom, Adv. Mater., 2008, 20, 2116-2119.

15 H. Xin, S. Subramaniyan, T.-W. Kwon, S. Shoaee, J. R. Durrant and S. A. Jenekhe, Chem. Mater., 2012, 24, 1995-2001.

16 M. C. Scharber, D. Wuhlbacher, M. Koppe, P. Denk, C. Waldauf, A. J. Heeger and C. L. Brabec, Adv. Mater., 2006, 18, 789-794.

17 G. Dennler, M. C. Scharber and C. J. Brabec, Adv. Mater., 2009, 21, 1323-1338.

18 C. H. Peters, I. T. Sachs-Quintana, W. R. Mateker, T. Heumueller, J. Rivnay, R. Noriega, Z. M. Beiley, E. T. Hoke, A. Salleo and M. D. McGehee, Adv. Mater., 2012, 24, 663-668.

19 N. Li, J. D. Perea, T. Kassar, M. Richter, T. Heumueller, G. J. Matt, Y. Hou, N. S. Gueldal, H. W. Chen, S. Chen, S. Langner, M. Berlinghof, T. Unruh and C. J. Brabec, Nat. Commun., 2017, 8, 14541.

20 A. Distler, T. Sauermann, H.-J. Egelhaaf, S. Rodman, D. Waller, K.-S. Cheon, M. Lee and D. M. Guldi, Adv. Energy Mater., 2014, 4, 1300693.

21 T. Heumueller, W. R. Mateker, A. Distler, U. F. Fritze, R. Cheacharoen, W. H. Nguyen, M. Biele, M. Salvador,
M. von Delius, H. J. Egelhaaf, M. D. McGehee and C. J. Brabec, Energy Environ. Sci., 2016, 9, 247-256.

22 L. P. Yan, J. D. Yi, Q. Chen, J. Y. Dou, Y. Z. Yang, X. G. Liu, L. W. Chen and C. Q. Ma, J. Mater. Chem. A, 2017, 5, 10010-10020.

23 L. Yan, Y. Wang, J. Wei, G. Ji, H. Gu, Z. Li, J. Zhang, Q. Luo, Z. Wang, X. Liu, B. Xu, Z. Wei and C.-Q. Ma, J. Mater. Chem. A, 2019, 7, 7099-7108.

24 A. Distler, T. Sauermann, H. J. Egelhaaf, S. Rodman, D. Waller, K. S. Cheon, M. Lee, N. Drolet and D. M. Guldi, Adv. Energy Mater., 2014, 4, 1300693.

25 W. J. E. Beek, M. M. Wienk, M. Kemerink, X. N. Yang and R. A. J. Janssen, J. Phys. Chem. B, 2005, 109, 9505-9516.

26 N. Wu, Q. Luo, Z. M. Bao, J. Lin, Y. Q. Li and C. Q. Ma, Sol. Energy Mater. Sol. Cells, 2015, 141, 248-259.

27 T. Heumueller, T. M. Burke, W. R. Mateker, I. T. SachsQuintana, K. Vandewal, C. J. Brabec and M. D. McGehee, Adv. Energy Mater., 2015, 5, 1500111.

28 T. Heumueller, W. R. Mateker, I. T. Sachs-Quintana, K. Vandewal, J. A. Bartelt, T. M. Burke, T. Ameri, C. J. Brabec and M. D. McGehee, Energy Environ. Sci., 2014, 7, 2974-2980.

29 Y. J. He, H. Y. Chen, J. H. Hou and Y. F. Li, J. Am. Chem. Soc., 2010, 132, 1377-1382.

30 S. Y. Shao, J. Liu, J. Bergqvist, S. W. Shi, C. Veit, U. Wurfel, Z. Y. Xie and F. L. Zhang, Adv. Energy Mater., 2013, 3, 349-355.

31 Y. W. Zhu, Z. C. Yuan, W. Cui, Z. W. Wu, Q. J. Sun, S. D. Wang, Z. H. Kang and B. Q. Sun, J. Mater. Chem. A, 2014, 2, 1436-1442.

32 F. X. Xie, W. C. H. Choy, C. D. Wang, X. C. Li, S. Q. Zhang and J. H. Hou, Adv. Mater., 2013, 25, 2051-2055.

33 Y. Yin, A. Sibley, J. S. Quinton, D. A. Lewis and G. G. Andersson, Adv. Funct. Mater., 2018, 28, 1802825.

34 M. T. Greiner, M. G. Helander, W.-M. Tang, Z.-B. Wang, J. Qiu and Z.-H. Lu, Nat. Mater., 2012, 11, 76-81.

35 M. T. Greiner, L. Chai, M. G. Helander, W.-M. Tang and Z.-H. Lu, Adv. Funct. Mater., 2012, 22, 4557-4568.

36 Y. Yin, X. Pan, M. R. Andersson, D. A. Lewis and G. G. Andersson, ACS Appl. Energy Mater., 2020, 3, 366-376.

37 S. Engmann, A. J. Barito, E. G. Bittle, N. C. Giebink, L. J. Richter and D. J. Gundlach, Nat. Commun., 2019, 10, 227.

38 Z. R. Li, J. K. Shan, L. P. Yan, H. M. Gu, Y. Lin, H. W. Tan and C. Q. Ma, ACS Appl. Mater. Interfaces, 2020, 12, 15472-15481.

39 B. Shamieh, S. Obuchovsky and G. L. Frey, J. Mater. Chem. C, 2016, 4, 1821-1828.

40 G. M. Paternò, V. Robbiano, K. J. Fraser, C. Frost, V. García Sakai and F. Cacialli, Sci. Rep., 2017, 7, 41013.

41 A. Kovtun, D. Jones, S. Dell'Elce, E. Treossi, A. Liscio and V. Palermo, Carbon, 2019, 143, 268-275. 